\title{
Kultura polityczna: czy tego można się nauczyć?
}

DOI 10.35757/CIV.2016.18.03

[...] jeśli pytasz ogólnie, na co się państwu tak bardzo przyda kultura ludzi dobrze wychowanych, to nietrudno odpowiedzieć, że ludzie dobrze wychowani moga się stać ludźmi dzielnymi, a jak się takimi stana, to $\mathrm{i} \mathrm{w}$ czym innym dobrze się im będzie wiodło i mogą w dodatku zwyciężać nieprzyjaciół w bitwach. Bo kultura przynosi także i zwycięstwo, choć zwycięstwo czasem obniża kulturę $[\ldots]$ Kultura nigdy nie przynosi zguby, a zwycięstwo już nieraz ludziom zgubę przyniosło i nieraz ja przynosić będzie ${ }^{1}$.

Cytat $z$ Platona, przywołany tutaj jako motto, pozwala mi już na początku zwrócić uwagę czytelnika na dwie rzeczy. Po pierwsze, na znaczenie, jakie $\mathrm{w}$ wymiarze politycznym wiąano $z$ kultura $\mathrm{w}$ czasach starożytnych, a po drugie, na powiązanie jej $z$ dobrym wychowaniem. Wprawdzie Platon nie pisze wprost o kulturze politycznej, znając jednak ówczesny kontekst historyczny i biorąc pod uwagę ówczesne utożsamianie kultury $z$ procesem doskonalenia człowieka, osiaganiem przez niego dzielności (cnoty),

Barbara Anna Markiewicz - profesor doktor habilitowany, jest absolwentka polonistyki Uniwersytetu Jagiellońskiego i filozofii Uniwersytetu Warszawskiego; kierownik Zakładu Filozofii Polityki w Instytucie Filozofii UW. Opublikowała około 300 prac naukowych; jej teksty ukazały się także w języku niemieckim, angielski i hebrajskim. Głównym przedmiotem jej zainteresowań jest historia filozofii, dydaktyka filozofii oraz filozofia polityki.

1 Platon: Prawa, w: idem, Państwo z dodaniem siedmiu ksiag "Praw", t. 2, przekład W. Witwicki, Warszawa, Państwowe Wydawnictwo Naukowe, Warszawa 1958, s. 295. 
która, według Greków, najlepiej manifestowała się w działalności obywatelskiej (piękne czyny), zasadnie można uznać, iż istotnym wymiarem kultury w czasach starożytnych była właśnie polityka. $Z$ kolei wskazanie na związek kultury $z$ dobrym wychowaniem w pewien sposób stanowi już odpowiedź na tytułowe pytanie. Dla Platona było czymś oczywistym, że uczymy się kultury politycznej jako umiejętności działania skutecznego, ale podejmowanego w imię dobra wspólnego. Proces dochodzenia do takich umiejętności i nabywanie tego rodzaju wiedzy przedstawia on między innymi w Państwie. Dzisiaj zwiąek ten nie jest już tak oczywisty. Przede wszystkim dlatego, iż pojęcie „kultury politycznej” w naszych czasach nie jest już tylko intuicyjnie zrozumiałe. Pełni funkcję fachowego terminu, którym operuje się na gruncie socjologii. W pewien sposób został już ustalony wzór tego pojęcia, który w dyskursie naukowym, dotyczacym kultury politycznej, musi zostać uwzględniony w pierwszej kolejności². Jego socjologiczny model opracowali Gabriel A. Almond i Sidney Verba, głównie na podstawie badań empirycznych i porównawczych nad systemami politycznymi USA, Wielkiej Brytanii, Niemiec Zachodnich, Włoch i Meksyku³. Wypada zatem przypomnieć, co rozumieli przez to pojęcie. Według nich:

\footnotetext{
2 Ustalenie wzoru pojęcia $z$ jednej strony zawsze otwiera nowe pole badawcze, $z$ drugiej inicjuje dyskusję, w toku której jego znaczenie jest modyfikowane i rozszerzane, co czyni zeń "pojęcie istotowo sporne”, czego dowodem sa także teksty przedstawione w niniejszym tomie "Civitas”. Na temat pojęć istotowo spornych por. Walter B. Gallie: Essentially Contested Concepts (1955-1956, wersja zmieniona 1965). Historyczne wzory pojęcia „kultura polityczna” można znaleźć także w polskiej literaturze politycznej: odwoływali się do niego Józef Milewski (1859-1916): Wykład o kulturze politycznej, odbitka z „Gazety Narodowej”, Gubrynowicz i Syn, [Lwów] 1912 oraz Jan Józef Siemieński (1882-1941) w odczycie: Konstytucya 3 maja 1791 jako wyraz polskiej kultury politycznej, [Warszawa] 1916. Na ten temat por.: K. Przybyszewski: Kultura publiczna. Refleksje wokół kondycji społeczeństwa i państwa polskiego, Uniwersytet Adama Mickiewicza w Poznaniu, Poznań 2012. Por. także: B. Markiewicz: Kultura polityczna - ujęcie klasyczne i jego modyfikacje, w: P. Żarkowski, S. Topolewski (red.): Wspótczesne bezpieczeństwo kulturowe, Wydawnictwo Uniwersytetu Przyrodniczo-Humanistycznego w Siedlcach, Siedlce 2014, s. 9-22.

3 Por. G.A. Almond, S. Verba: The Civic Culture. Political Attitudes and Democracy in Five Nation, Little, Brown, Boston 1965. Fragmenty tej pracy w tłumaczeniu Jerzego Lozińskiego ukazały się w: J. Szczupaczyński (red.): Władza i społeczeństwo. Antologia tekstów z zakresu socjologii polityki, Wydawnictwo Naukowe Scholar, Warszawa 1995, s. 328-344.
} 
Pojęcie „kultury politycznej” odsyła nas [...] do specyficznie politycznego nastawienia: do postaw wobec ustroju politycznego w całości i jego fragmentów oraz do oceny roli, jaką w ramach systemu może odegrać jednostka. O kulturze politycznej mówimy na tej samej zasadzie, na której mówić można o kulturze ekonomicznej czy religijnej; chodzi nam o kompleks postaw wobec specyficznego zestawu obiektów i procesów społecznych ${ }^{4}$.

W ujęciu zaproponowanym przez Almoda i Verbę kultura polityczna może stać się przedmiotem badań głównie dlatego, iż przejawia się na poziomie fenomenalnym jako określone, kompleksowe, zachowanie (orientacja) i postawa obywateli. Ich podstawowym punktem odniesienia jest ustrój polityczny, w którym żyja, i jego różne instytucje, określane jako specyficzny zestaw „społecznych obiektów i procesów”. Zawiera się w niej również sposób, w jaki jednostki w danym ustroju realizuja się jako obywatele. Przy czym chodzi o ustrój polityczny rozumiany jako „uwewnętrzniony przez członków danej populacji poprzez poznanie, uczucia i ewaluację"

Ustrój polityczny zatem, to nie tylko, jak się okazuje, system prawny, instytucje czy powiazany $z$ nim system aksjologiczny. Tematem zainteresowania Almonda i Verby staje się takie jego rozumienie, które za Edmundem Husserlem, określić by można jako świat życia, bo tylko w ten sposób zobiektywizowana poprzez system prawny rzeczywistość polityczna może się stać przedmiotem doświadczenia wewnętrznego. Na podstawie takiego doświadczenia kształtuja się dopiero postawy i motywacje do działania poszczególnych obywateli. Przy czym warto pamiętać, że badanie postaw obywateli nie miało jedynie charakteru diagnostycznego, ale przede wszystkim prognostyczny. Miało pozwolić, jak sadzili Almond i Verba, na określenie tendencji i sposobów zachowań politycznych obywateli, co $z$ kolei dawało szansę na wyjaśnienie i przewidywanie zjawisk politycznych.

${ }_{4}$ Por. G.A. Almond, S. Verba: The Civic Culture, s. 12 [thumaczenie własne - B.M.].

5 Ibidem, s. 13. 
W zamierzeniu Almonda i Verby pojęcie kultury politycznej stanowiło niejako pomost, pozwalający na przejście od badań politycznej rzeczywistości na poziomie bezosobowych instytucji do poziomu zachowań jednostek. Miało bowiem wyjaśniać, w jaki sposób pojedynczy obywatele reagują w zetknięciu z politycznymi strukturami i instytucjami.

Założenie, iż podstawa studiów nad kultura polityczna sa badania indywidualnych postaw obywateli, wiązało się jednak, szczególnie na poziomie empirycznym, $z$ poważnymi trudnościami metodologicznymi. Po pierwsze, należało zdecydować, jak duża miała być badana grupa obywateli, aby była reprezentatywna analizy przedstawione w Civic Culture opierały się na próbie wynoszącej pięć tysięcy osób. I po drugie, należało skonstruować właściwy kwestionariusz, który pozwoliłby zróżnicować i zbadać uwewnętrznione przez obywateli postawy poznawcze, emocjonalne i ich system ocen. Według Almonda i Verby zanalizowanie takich jednostkowych postaw wymagało uzyskania wiedzy od badanych $z$ następujących zakresów: 1) na temat ich własnego narodu, w tym jego politycznego systemu, wielkości, położenia, siły, charakteru ustrojowego, a także opinii i uczuciowego stosunku danej jednostki do tych spraw; 2) na temat struktur politycznych w ich państwie, roli różnych elit oraz procesu podejmowania decyzji politycznych, a także oceny i stosunku uczuciowego danej jednostki do przywódców politycznych i wysuwanych przez nich propozycji; 3) na temat sposobu realizacji polityki w ich państwie i stosunku uczuciowego danej jednostki do politycznej praktyki. Do takiego kwestionariusza miały zostać także dołączone pytania, dotyczace własnej oceny przez jednostkę siebie jako członka systemu politycznego, wiedzy o swoich prawach, możliwościach, zobowiązaniach i strategiach pozwalających wpływać na politykę oraz tego, jakie normy uczestnictwa i skuteczności odgrywają rolę przy formułowaniu przez tę jednostkę ocen politycznych.

Jak wynika $z$ przeprowadzonych przez Almonda i Verbę ankiet, istotnym elementem obywatelskich kompetencji, stanowią- 
cych o kulturze politycznej, staje się rozległa wiedza o własnym kraju i narodzie, o panujacym systemie politycznym i sposobie jego funkcjonowania (o roli różnych elit) oraz o procesie podejmowania decyzji politycznych i ich realizacji. Ponieważ stawiane przez nich pytania dotyczyły jednocześnie oceny i uczuciowego stosunku obywateli do tej wiedzy, wymogom stawianym kulturalnym obywatelom sprostać mogli, jak się wydaje, jedynie ludzie w miarę wykształceni i posiadający dość wysoki stopień samowiedzy.

Na gruncie bardzo pogłębionych badań, Almond i Verba, uznawszy, iż podstawa do określenia kultury politycznej badanych populacji jest zbieżność i częstotliwość pewnych odpowiedzi, sygnalizujacych określone postawy, wyróżnili trzy podstawowe typy kultury politycznej: zaściankowa (po polsku tłumaczona także jako parafialna), podporządkowana i uczestnictwa. W rzeczywistości, jak się jednak okazało, kultura polityczna nigdy nie jest jednolita, każdy obywatel bowiem prezentuje postawę stanowiąca mieszaninę tych wyróżnionych modeli. Dodatkowo jeszcze same badania, a przede wszystkim budowane na nich prognozy, musiały również uwzględniać fakt, iż kultura polityczna ma charakter dynamiczny. Postawy obywateli wszak zmieniaja się, dochodzi także do rozbieżności, a nawet konfliktów między ich kultura polityczna a struktura systemu politycznego. $Z$ tego także powodu podstawowa niejako jednostką kultury politycznej stała się u Almonda i Verby „kultura obywatelska" (civic culture), charakteryzowana jako mieszanina kultur politycznych i zbliżona, na co sami autorzy zwrócili uwagę, do pojęcia „kultury osobistej”6. Co więcej, autorzy ci opracowali normatywny model takiej kultury. Zgodnie $z$ nim obywatel, charakteryzujący się kultura obywatelska, to mieszkaniec państwa demokratycznego, żywo interesujący się polityka, czyli dobrze poinformowany i podejmujacy decyzje polityczne na podstawie dokładnego przemyślenia zasad i działań, które chciałby wspierać. Miałby to być również człowiek, podejmujący decyzje po zapozna-

\footnotetext{
6 Por. także G.A. Almond: Intelektualny rodowód pojęcia obywatelskiej kultury politycznej,
} „Studia Nauk Politycznych” 1986, nr 1, s. 7-39. 
niu się $z$ prezentowanymi przez polityków programami ${ }^{7}$. Przy czym takie polityczne zaangażowanie i racjonalizm powinny iść $\mathrm{w}$ parze $z$ akceptacja i szacunkiem dla lokalnej i narodowej tradycji oraz związanych $z$ nią wartości.

Ten model kultury politycznej oraz powiazanej $z$ nim politycznej świadomości i powstałej na tej podstawie politycznej tożsamości odwołuje się przede wszystkim do racjonalnego obywatelskiego działania i aktywnego włączania się w struktury inicjatywne. Autorzy Civic Culture określili tę postawę jako „racjonalistyczny aktywizm" i powiązali $z$ obywatelska kultura lojalnego uczestnictwa, charakterystyczna dla wyidealizowanego modelu obywatela państwa demokratycznego oraz dla związanej $z$ nim politycznej tożsamości obywatelskiej.

Podkreślenie znaczenia racjonalnego zaangażowania i działania w postawie obywateli pozwala, jak sądzę, zestawić koncepcję Almonda i Verby $z$ modelem obywatela, jaki pojawia się w kontekście politycznego liberalizmu u Johna Rawlsa. Z punktu widzenia interesujacej mnie tematyki zestawienie to jest istotne, ponieważ Rawls podejmuje kwestię edukacji obywatelskiej. W ten sposób będzie można, jak mi się wydaje, połączyć kwestię kultury obywatelskiej i obywatelskiej edukacji, co w istotny sposób przybliży nas do odpowiedzi na pytanie postawione $\mathrm{w}$ tytule niniejszego tekstu. Najpierw jednak należy określić miejsce, jakie w procesie edukacji obywatelskiej przypada kulturze politycznej, która Rawls sytuuje na poziomie podstawowych idei politycznych ${ }^{8}$.

Idea obywatela stanowi u Rawlsa ideę towarzysząca koncepcji społeczeństwa jako systemu sprawiedliwej kooperacji poprzez pokolenia. Aby ta kooperacja była możliwa, obywatele muszą być

\footnotetext{
7 Por. G.A. Almond, S. Verba: The Civic Culture, s. 29.

8 Kulturę polityczna, lub jak nazywa ja także Rawls kulturę publiczna, społeczeństwa demokratycznego charakteryzuja, jego zdaniem, trzy ogólne fakty: 1) pluralizm rozległych rozumnych doktryn, 2) narzucenie jednej rozległej doktryny wymaga użycia przemocy państwa, 3) trwały ustrój demokratyczny musi znaleźć poparcie znacznej większości obywateli, wyznających różne rozumne rozległe doktryny. (Por. J. Rawls: Liberalizm polityczny, przekład A. Romaniuk, Wydawnictwo Naukowe PWN, Warszawa 1998, s. 74 i nn.) Nie jest to jednak kultura obywatelska.
} 
osobami wolnymi i równymi. O wolności obywateli decydować będzie, jak twierdzi Rawls, ich racjonalność i rozumność ${ }^{9}$. Obywatele natomiast sa równi, choćby nawet tylko w niezbędnym, minimalnym stopniu, ponieważ posiadaja dwie władze moralne. Jest to: 1) zdolność do posiadania poczucia sprawiedliwości i 2) zdolność do kierowania się jakąś koncepcją dobra ${ }^{10}$. Już na poziomie władz moralnych, które decyduja o zdolności osoby do bycia obywatelem, zaznacza się istotna dla całej politycznej koncepcji Rawlsa struktura, czyli podział na ideę sprawiedliwości i rozumne rozległe doktryny. Poczucie sprawiedliwości czyni nas zdolnymi do ugody dotyczącej politycznej koncepcji sprawiedliwości. Jeśli zaś chodzi o koncepcję dobra, to kształtuje się ona w obrębie naszych rozległych rozumnych doktryn. W ten sposób Rawls usuwa ze swojego pola widzenia klasyczna dyskusje $z$ zakresu filozofii politycznej, czyli dyskusję na temat dobra wspólnego. Co więcej, rozłącza także ideę dobra i ideę sprawiedliwości.

W zwiąku $z$ problemem nabywania kompetencji, określonych jako kultura polityczna, bardzo istotne wydaje się powiąanie racjonalności i władzy moralnej obywateli. Wrażliwość moralna właściwa rozumności określać powinna, jak twierdzi Rawls, pragnienia obywateli, a te stanowia podstawę ich działania. Stąd tak dużo miejsca poświęca on "psychologii moralnej"11. Jest to ważne, ponieważ aby dobrze urządzone społeczeństwo było stabilne, to obowiazujące $\mathrm{w}$ nim zasady nie tylko powinny być znane i akceptowane przez obywateli, ale przede wszystkim praktykowane, czyli przestrzegane przez nich w działaniu. To znaczy powinny one

\footnotetext{
9 W obrębie idei sprawiedliwej kooperacji rozumność i racjonalność sa ideami komplementarnymi, ale nie da się ich ze sobą powiązać czy wywieść jednej z drugiej. Działaja w tandemie i każda wiąże się $z$ odpowiednią władzą moralną: rozumność ze sprawiedliwościa, racjonalność z koncepcją dobra. Por. Ibidem, s. 52 i nn.

${ }^{10}$ Ibidem, s. 405.

${ }^{11}$ Sformułowane przez Rawlsa trzy prawa psychologiczne odnoszace sie do sprawiedliwości układu instytucjonalnego wyznaczają wewnętrzne powiązanie między miłością w obrębie rodziny (pierwsze prawo), przyjaźnią na poziomie społecznym (drugie prawo) i akceptacja dla sprawiedliwego porządku politycznego i lojalnością wobec niego (trzecie prawo). Por. J. Rawls: Teoria sprawiedliwości, przekład M. Panufnik et al., Wydawnictwo Naukowe PWN, Warszawa 1994, s. 664-665.
} 
regulować postępowanie ludzi we wzajemnych stosunkach (rodzina, wspólnota, społeczeństwo polityczne itp.).

Do charakterystyki obywatela żyjącego i działającego w liberalnej demokracji należy dodać jeszcze jeden ważny dla tej tradycji element. Za Emmanuelem Kantem można go określić jako wymóg cywilizacyjny, czyli wymóg civility, na język polski tłumaczony jako wymóg grzeczności. Z przyjętej przez Rawlsa zasady legitymizacji porząku demokratycznego wynika, iż obowiazujący w nim ideał obywatelstwa wiaże się ściśle $z$ obowiązkiem grzeczności, który ma charakter moralny i jest rozpatrywany w kontekście „publicznego rozumu”. W ujęciu Rawlsa oznacza to: po pierwsze, że obywatele powinni „być w stanie wyjaśnić sobie nawzajem w odniesieniu do tych kwestii podstawowych, jak zasady i kierunki postępowania politycznego, których się jest rzecznikiem i na które się głosuje, moga znaleźć oparcie w politycznych wartościach publicznego rozumu” oraz, po drugie, „gotowość wysłuchania innych i bezstronność $\mathrm{w}$ decydowaniu o tym, kiedy rozumnie jest poczynić ustępstwa wobec ich poglądów"12. Przy czym te cywilizowane zasady, którymi powinien się kierować obywatel $\mathrm{w}$ relacji $\mathrm{z}$ innymi obywatelami obowiąuja jedynie, gdy w państwie przestrzega się liberalnej zasady legitymacji władzy, tzn. kiedy sama władza jest cywilizowana. Według Ralwsa, sprawowanie władzy politycznej jest właściwe (cywilizowane), a więc da się uzasadnić, tylko wtedy, gdy, jak pisze:

sprawujemy ja w zgodzie $\mathrm{z}$ konstytucja, co do której najważniejszych postanowień można rozsądnie oczekiwać, że wszyscy obywatele je popra, kierując się zasadami i ideami, które są dla nich, jako osób rozumnych, do przyjęcia $^{13}$.

\footnotetext{
${ }_{12}$ Por. J. Rawls: Liberalizm polityczny, s. 299 i nn.

${ }_{13}$ Ibidem, s. 299 i nn. Jak z tego wynika zasady grzeczności, o których pisze Rawls, nie sa tożsame $z$ zasada poprawności politycznej. Poprawność polityczna stanowi formę samoograniczenia obywatela w celu zmniejszenia poziomu uprzedzeń i dyskryminacji w sferze publicznej. Wyraża się to m.in. w dyskursie publicznym (unikanie wyrażeń i zwrotów, które moga być obraźliwe) i przede wszystkim w sferze symbolicznej. Wprawdzie także w koncepcji poprawności politycznej przyjmuje się zasadę sprawiedliwości w stosunku do wykluczonych, lecz jest to sprawiedliwość etnokulturowa (rodzaj sprawiedliwości globalnej), Rawls natomiast jako założenie przyjmuje koncepcję społeczeństwa zamkniętego (por. J. Rawls: Libera-
} 
W ten sposób działania obywateli wpisują się w realistyczno-utopijny projekt Rawlsa. Chodzi o ideę społeczeństwa zdolnego do dobrego urządzenia konstytucyjnej demokracji przez powszechna akceptację idei sprawiedliwości, dokonaną dzięki częściowemu rozumnemu konsensowi. Wydaje mi się, iż w kontekście tego projektu obowiązek grzeczności, zasada cywilizująca byłaby dla Rawlsa najważniejszym wyrazem kultury politycznej. Za W. Kymlicka można ją także scharakteryzować jako:

kulture pluralistyczna, której podstawa jest dyskusja i przekonywanie, kulturę porozumienia (consensus) i zróżnicowania, kulturę dopuszczającą zmiany, lecz hamująca ich gwałtownośćc ${ }^{14}$.

Zapytajmy zatem raz jeszcze, w jaki sposób jednostki nabywaja takich kompetencji, których wyrazem staje się zasada grzeczności, czyli kultura polityczna. Zarówno w projekcie kultury obywatelskiej przedstawionym przez Almonda i Verbę, jak i w propozycji Rawlsa, chociaż w mniejszym zakresie, dużą rolę odgrywa wiedza nabyta. W procesie zdobywania wiedzy należy jednak, jak sądzę, wyróżnić dwa poziomy: wychowawczy i edukacyjny. Chodzi o wychowanie jako kontrolowane kształtowanie różnych cech osobowości oraz nauczanie jako przekazywanie określonej wiedzy i umiejętności ${ }^{15}$. W nowoczesnych państwach treści wychowawcze oraz te, będace przedmiotem świadomego nauczania choć w różnym stopniu i na różnych szczeblach, zostawały $z$ upływem czasu poddawane kontroli instytucji politycznych. Rejestrując ten trend w rozwoju edukacji publicznej, liberalizm klasyczny dostrzegał w nim głów-

$\overline{l i z m}$ polityczny, s. 405). Zgodnie z przyjętymi w koncepcji poprawności politycznej założeniami do obowiazków państwa obok zabezpieczenia uniwersalnych praw człowieka dla każdego obywatela należy stworzenie specyficznych praw dla grup mniejszościowych i kulturowych, tak aby dotychczas wykluczeni i imigranci mogli uczestniczyć w ogólnej kulturze publicznej społeczeństwa. Por. W. Kymlicka: Multicultural Citizenship. A Liberal Theory of Minority Rights, Clarendon Press, Oxford 1995.

${ }^{14}$ W. Kymlicka: Multicultural Citizenship, s. 6.

${ }^{15} \mathrm{Na}$ temat modelu edukacji u Rawlsa por.: B. Markiewicz: Politics as a System of Education, w: E. Czerwińska-Schupp (red.): Values and Norms in the Age of Globalization, Peter Lang Europeischer Verlag der Wissenschaften, Frankfurt am Main 2007, s. 273-289. 
nie zagrożenie dla wolności jednostkowej. Dotyczyło to szczególnie wychowania, czyli edukacji moralnej, która - zdaniem np. Johna Locke'a - powinna być przede wszystkim przedmiotem troski rodziców i pozostawać w sferze prywatnej ${ }^{16}$. Nauczanie, szczególnie zawodowe, Locke był skłonny powierzyć władzy państwowej. Kiedy jednak władza polityczna usiłuje przejąć odpowiedzialność za formowanie charakteru obywateli, to przekracza, według niego, właściwy sobie obszar działań, tj. sferę publiczna. Wkraczając bowiem w przestrzeń życia prywatnego, zagraża podstawowym prawom jednostki do wolności i jej dążeniu do szczęścia.

Jeśli chodzi o Rawlsa, to proces edukacyjny interesuje go przede wszystkim o tyle, o ile służy zdobywaniu przez obywateli kompetencji potrzebnych do uczestniczenia w sferze polityki. Celem edukacji, według Rawlsa, powinno być przygotowanie dzieci, aby były „w pełni kooperujacymi członkami społeczeństwa” i doprowadzenie ich do samodzielności albo „by potrafiły stanać na własnych nogach"17. Wynika $z$ tego, że najważniejszym elementem w edukacji dzieci $z$ punktu widzenia społecznej i politycznej stabilności społeczeństwa jest jej znaczenie polityczne, stąd należy zadbać o jej właściwą treść. Według Rawlsa:

Troska społeczeństwa o ich edukację dotyczy ich roli jako obywateli, a więc rzeczy tak niezbędnych, jak to, by nabyły zdolności rozumienia jego publicznej kultury i uczestniczenia w jego instytucjach oraz by stały się niezależnymi i zdolnymi do samodzielnego utrzymania się członkami społeczeństwa przez całe życie rozwinęły w sobie cnoty polityczne - wszystko to ma być rozpatrywane $z$ politycznego punktu widzenia ${ }^{18}$.

W procesie edukacji powinny, jego zdaniem, zostać także uwzględnione takie elementy, jak rozwój zdolności intelektualnych, przekazywanie wiedzy i umiejętności zawodowych oraz wychowanie moralne, stanowiące podstawę zdolności do kooperacji. Spro-

\footnotetext{
${ }^{16}$ Por. J. Locke: Myśli o wychowaniu, przekład F. Wnorowski, Zakład Narodowy im. Ossolińskich Wydawnictwo PAN, Wrocław 1959.

17 J. Rawls: Liberalizm polityczny, s. 277.

${ }^{18}$ Ibidem, s. 278.
} 
wadzone do takiego katalogu, treści modelu edukacji proponowanego przez teorię idealna Rawlsa nie zawieraja w sobie, jak się wydaje, żadnych nowych elementów w stosunku do tych, które obowiazuja w państwach o ustroju demokratycznym. Kiedy jednak Rawls mówi tutaj o „trosce społeczeństwa”, to sygnalizuje, iż ten model edukacji nie może zostać odgórnie nakazany czy wprowadzony przez władze polityczne. Powinien się pojawić jako wynik działań obywatelskich, podejmowanych w sferze publicznej, która, jak pamiętamy, jest odróżniona u Rawlsa od sfery politycznej, stanowiąc jej tło, czy raczej zaplecze.

Raz jeszcze daje w tym miejscu o sobie znać owo rozróżnienie, zauważalne na każdym poziomie dobrze urządzonego społeczeństwa, czyli podział na obszar polityczny (powszechnej zgody co do idei sprawiedliwości) i różniących się między sobą rozległych doktryn rozumnych. Warto także pamiętać, iż u Rawlsa rozróżnienie sfery publicznej i niepublicznej nie odpowiada tradycyjnemu podziałowi na sferę publiczna i prywatna, ponieważ dotyczy on różnych obszarów racjonalności, a według Rawlsa nie ma czegoś takiego jak rozum prywatny.

Zgodnie $z$ koncepcja Rawlsa edukacja początkowa, obejmująca również edukację moralną, ma na celu wszczepienie dzieciom poczucia sprawiedliwości i pozostaje w gestii rodziców, a jej kształt określaja wyznawane przez nich rozumne rozległe doktryny, które wyznaczaja także styl ich życia. Uznając, iż wychowanie dzieci zależy od stylu życia ich rodziców, Rawls nawiąuje do jednego $z$ najważniejszych elementów klasycznego liberalizmu. Jak stwierdził Steven Macedo:

Liberalizm utrzymuje, że rozumni ludzie maja prawo realizować szeroki zakres stylów życia, celów, przedsięwzięć i wartości. Jedna z najbardziej pociagajacych cech liberalnej polityki i koncepcji człowieka jest właśnie to, że uwalniaja one ludzi od odziedziczonych ról, sztywnych hierarchii i konwencji wąsko ograniczających indywidualność i zakres wyboru. Liberalna rozumność musi być dostatecznie szeroko pojęta, by obejmować różnorodność: musi dostosować się do liberalnego zróżni- 
cowania publicznej racjonalności i krytycznej refleksji na temat ról i więzi osób ${ }^{19}$.

Pojawia się jednak zasadnicza trudność. W jaki sposób te różne modele edukacji, zakorzenione w odmiennych rozumnych doktrynach, czyli w odmiennych stylach życia, systemach wartości, a więc także powiązane $z$ różnymi koncepcjami człowieka, maja się składać na wspólny model obywatela społeczeństwa dobrze urządzonego? Przy wyjaśnianiu tego $z$ góry możemy odrzucić ideę „niewidzialnej ręki rynku”, gdyż nie uwzględnia ona idei sprawiedliwości, jak również koncepcję „przedustawnej harmonii”, ponieważ wywodzi się z bardzo określonej filozoficznej doktryny (Leibniz).

Moim zdaniem, Rawls jeszcze w Teorii sprawiedliwości zaproponował takie rozwiąanie tego problemu, które nasuwa porównanie $z$ innym wielkim systemem filozoficznym, czyli $z$ teoria emanacji Plotyna. Uznał bowiem, iż poczucie sprawiedliwości (sense of justice) jako cel wychowania moralnego, nie może się pojawić, jak już wspomniałam, w wyniku przymusowej indoktrynacji czy psychologicznego treningu. Odrzucił także edukację moralną, pojmowana jako „łańcuch przyczynowy”, którego ostatecznym wynikiem okazałoby się powstanie odpowiednich więzi moralnych. Dlatego postulował on stopniowe, dostosowane do poziomu nauczania przyswajanie sobie idei sprawiedliwości, obcowaniu $z$ nią. Jak pisze Rawls:

W takiej mierze, w jakiej jest to możliwe, każde stadium ucząc i wyjaśniając, zapowiada koncepcje sprawiedliwości, na która jest nakierowane; odniesienie do tej koncepcji sprawia, że w dalszej kolejności przekonamy się, iż przedstawione nam standardy sa uzasadnione ${ }^{20}$.

Taki emanacyjny model edukacji moralnej sprawdzał się w sytuacji, w której strony uczestniczące w umowie społecznej były wyposażone w pewien zasób wiedzy ogólnej, bo tylko przez odnie-

${ }_{19}$ S. Macedo: Cnoty liberalne, przekład G. Łuczkiewicz, Wydawnictwo Znak, Kraków 1995, s. 258 .

20 J. Rawls: Teoria sprawiedliwości, s. 698. 
sienie do niej mogły określić kolejne stopnie nabywanej wiedzy, kolejne zasady sprawiedliwości. Kiedy jednak Rawls w Liberalizmie politycznym zradykalizował wymagania dotyczace sytuacji pierwotnej, usuwając $z$ niej także wiedzę ogólna, problem ten powrócił. Co więcej, wystapiła dodatkowa trudność, związana $z$ samym liberalizmem politycznym Rawlsa. Ponieważ liberalizm polityczny stanowi również rodzaj wiedzy ogólnej, to pojawia się pytanie o jego miejsce i funkcję $\mathrm{w}$ edukacji moralnej obywateli, czy w edukacji politycznej w ogóle.

Jak zauważa sam Rawls, to właśnie głównie w obszarze edukacji czai się niebezpieczeństwo przekształcenia liberalizmu politycznego w jedna $z$ wielu rozległych rozumnych doktryn, mających ambicję kierowania większością lub nawet całym życiem człowieka (jak ma to, według niego, miejsce w wypadku liberalizmu Immanuela Kanta czy Johna Locke'a). Może to być, jak z żalem przyznaje Rawls, pewna „nieunikniona konsekwencja rozumnych wymagań, co do wychowania dzieci”. Jednak liberalizm polityczny, jego zdaniem, nie ma ambicji ogarniania całego życia. Posiada on inny cel i wymaga dużo mniej. Jak twierdzi Rawls:

Będzie on żądał, by edukacja dzieci zawierała takie rzeczy, jak wiedza o ich konstytucyjnych i obywatelskich prawach, tak aby na przykład wiedziały, że w ich społeczeństwach istnieje wolność sumienia i że apostazja nie jest przestępstwem, a wszystko to ma zapewnić, by ich dalsza przynależność, gdy dorosna, nie opierała się po prostu na niewiedzy o ich podstawowych prawach i strachu przed kara za przestępstwa, które nie istnieja ${ }^{21}$.

Okazuje się zatem, że liberalizm polityczny sam nie oferuje jakiegoś określonego modelu edukacji, on tylko wysuwa pod adresem edukacji publicznej, różnych jej form, pewne żądania, tak aby była ona zdolna do kształcenia odpowiednich obywateli. Również sposób formułowania tych żądań, jak na liberalizm przystało, nie może mieć charakteru nakazowego, twardego. Rawls optuje

${ }^{21}$ J. Rawls: Liberalizm..., s. 276. 
za miękkimi rozwiązaniami. Dlatego właśnie wydaje mu się, iż taka funkcje jednoczaca $\mathrm{w}$ obszarze politycznym, pozwalająca zorganizować różne koncepcje edukacji, aby służyły stabilności dobrze urządzonego społeczeństwa, pełnić może sama „idea sprawiedliwości jako bezstronności”. Jest on bowiem przekonany, iż stosowna idea polityczna (taka jak np. idea sprawiedliwości) jest wyposażona równocześnie w funkcję edukacyjną. Dokonuje zatem Rawls znamiennego utożsamienia pewnego określonego porządku politycznego $z$ porzadkiem edukacji.

Jeśli zestawimy różne elementy konstrukcji politycznej Rawlsa, to okaże się, iż dobrze urządzone społeczeństwo, jako wynik respektowania idei sprawiedliwości jako bezstronności, tworzy pewien wzór, który określa możliwe formy społecznej i politycznej działalności. To $z$ niego także wynika model obywatela i osoby. I dlatego także w stosunku do obywateli może on odgrywać rolę edukacyjna, promujac określone zachowania i wzory osobowe. W takim ujęciu właściwy model polityczny (polityczny liberalizm) tworzy podstawę dla kształcenia zarówno kultury osobistej (przez właściwy model rodziny), jak i kultury politycznej. W tej perspektywie propozycja Rawlsa byłaby bardzo bliska koncepcji kultury politycznej w znaczeniu kultury obywatelskiej - tej, która zaproponowali Almond i Verba. Do jej uformowania niezbędna jest kultura osobista, czyli właściwe wychowanie w rodzinie, w kręgu rozległych rozumnych doktryn, oraz wiedza nabyta w strukturach instytucjonalnych (głównie szkoła). Zgodnie $z$ pierwszym prawem moralnym, sformułowanym przez Rawlsa, na poziomie rodziny dziecko nabywa kompetencji silnie wiązacych go $z$ bliskim osobami przez „przyswojenie sobie przywiazania”. Jeśli wchodzi w sprawiedliwy system społeczny to u osoby wychowanej w miłości wykształcaja się, jak chce Rawls:

więzi przyjaźni i zaufania do innych członków stowarzyszenia, jeśli tylko ci w widoczny sposób wypełniaja swe obowiazki i zobowiąania oraz żyja zgodnie $z$ ideami związanymi $z$ ich pozycja $\mathrm{w}$ społeczeństwie ${ }^{22}$.

22 J. Rawls: Liberalizm..., s. 664-665. 
W ten sposób dziecko nabywa umiejętności społecznego współżycia, rozwijając swoje poczucie sprawiedliwości. Problem polega jednak na tym, że powstająca $\mathrm{w}$ ten sposób kultura polityczna, której podstawą jest idea sprawiedliwości jako bezstronności, w żaden sposób nie gwarantuje ukształtowania właściwych postaw i zachowań politycznych obywateli, czyli wspierających przez aktywne uczestnictwo (partycypację) ustrój liberalnej demokracji. Jeśli szkolna edukacja ma wyrównywać różnice, jakie generuje wychowanie $\mathrm{w}$ rodzinie, na zasadzie, jak chce Rawls, kompensacji, to nie wydaje się, aby to społeczne zróżnicowanie można było zneutralizować przez odwołanie się jedynie do idei braterstwa czy słuszności ${ }^{23}$.Wprawdzie Rawls uprzedza te watpliwości, zgłaszajac swoje projekty pod hasłem realistycznej utopii, niemniej w istniejących warunkach oprócz idealistycznych możliwości, które rozwija w swoich pracach, trzeba także dostrzegać zagrożenia mogace utrudniać albo nawet uniemożliwiać zrealizowanie się scenariuszy optymistycznych. W odniesieniu do kultury politycznej jako pewnego projektu edukacyjnego, czyli powiąanego $z$ idea sprawiedliwości, demokratycznego i konstytucyjnego ustroju, warto, jak sądzę, wspomnieć tutaj o dwóch takich współczesnych zagrożeniach.

Po pierwsze, jako zagrożenie dla liberalnie pojmowanego projektu edukacji obywatelskiej, mającego stanowić podstawę obywatelskiej, politycznej kultury, traktować można pogłębianie się nierówności wynikajacych $z$ rozwarstwiania poziomów kultury osobistej wyniesionej przez dzieci $z$ domu. To zagrożenie stanowi, jak sądzę, jeden $z$ wielu wymiarów współcześnie zdiagnozowanego kryzysu demokracji i liberalizmu w ogóle. Drugie zagrożenie wiąże się, moim zdaniem, $z$ rozwojem nowych mediów i powiązanej $z$ nim zmiany formy sfery publicznej, w tym także formy politycznej, obywatelskiej aktywności.

$\mathrm{Na}$ destabilizujące społecznie znaczenie nierówności w dostępie do zasobów wiedzy i kultury zwrócił uwage Pierre Bourdieu. Podstawowa kategoria, która pozwala, według niego, wyjaśnić dzi-

${ }^{23}$ Por. J. Rawls: Teoria sprawiedliwości, s. 144. 
siejszą formę społecznego zróżnicowania, jest szeroko pojmowane przez niego pojęcie „kapitału”24. Według Bourdieu jako kapitał traktować można również dobra i zasoby pozaekonomiczne, łącznie $z$ wiedzą szkolną i kulturą. Podobnie jak środki ekonomiczne, również kapitał szkolny i kulturowy pozwala określić miejsce jednostki w strukturze społecznej, określając jej zasoby i możliwości ich pomnożenia. Przy czym kapitał szkolny to wiedza, która nabywamy na różnych etapach kształcenia, a sposób jej nabywania jest zapośredniczony przez instytucjonalny system edukacji. Kapitał kulturowy - na który składa się m.in. obeznanie $z$ wysoką kulturą (np. znajomość muzyki czy malarstwa), gusta, sposoby życia i towarzyska ogłada - powstaje przez pokolenia w obrębie rodziny i po niej go bezpośrednio dziedziczymy. W ten sposób kształtuje się dominacja kulturowa, na którą składa się cały system symboliczny, wypracowany w obrębie danego społeczeństwa. Jak zauważa Tomasz Zarycki, analizujac ten element koncepcji Bourdieu:

Szkoły (od przedszkoli po uniwersytety) sa w takim ujęciu tylko jedna $z$ licznych instytucji systemu hegemonii kulturowej. Stanowia one oczywiście bardzo ważne ogniwa systemu, będąc kluczowymi instytucjami legitymizujacymi i socjalizującymi swoich podopiecznych do dominujacego systemu wartości kulturowych. Jak jednak przekonuje Bourdieu, funkcja socjalizacyjna szkoły jest $\mathrm{w}$ takim przypadku $\mathrm{w}$ istocie wtórna, ponieważ kluczowy etap socjalizacji, przesadzający w znacznej mierze o zasobach kapitału kulturowego oraz predyspozycjach do jego mnożenia, a więc habitusie, ma miejsce $\mathrm{w}$ rodzinie ${ }^{25}$.

\footnotetext{
${ }^{24} \mathrm{~W}$ ujęciu Bourdieu kapitał to: „zakumulowana praca (w jej materialnej formie lub w jej "uprzedmiotowionej", wcielonej w coś formie), która o ile zostanie przywłaszczona na prywatnej, tzn. wyłącznej bazie, przez jakąs osobę lub grupę osób, umożliwia im zawłaszczanie energii społecznej w formie uprzedmiotowionej lub żywej pracy". P. Bourdieu: The forms of capital, w: J.G. Richardson (red.): Handbook of theory and research for sociology of education. Greenwood Press, Westport, CT 1986, s. 253, cyt. za: T. Zarycki: Kapitał kulturowy - założenia i perspektywy zastosowań teorii Pierre'a Bourdieu, <http://www.iss.uw.edu.pl/ zarycki/pdf/kapkult.pdf>, s. 13 [dostęp: 5 lutego 2016 r.]. Por. także P. Bourdieu: Dystynkcja. Społeczna krytyka władzy sądzenia, przekład P. Biłos, Wydawnictwo Naukowe Scholar, Warszawa 2000.

${ }^{25}$ Por. T. Zarycki: Kapitał kulturowy - założenia i perspektywy zastosowań teorii Pierre'a Bourdieu, <http://www.iss.uw.edu.pl/zarycki/pdf/kapkult.pdf>, s. 14 [dostęp: 5 lutego 2016 r.].
} 
Według Bourdieu, system szkolny zatem nie tylko nie jest w stanie zniwelować różnic powstających $\mathrm{w}$ wyniku wychowania $\mathrm{w}$ rodzinie, ale wręcz te różnice utrwala, pogłębiając nierówność życiowych szans $\mathrm{w}$ obrębie tego samego pokolenia.

$Z$ przedstawionych powyżej analiz wynika, iż kultura polityczna, obywatelska, kształtuje się już na poziomie rodziny, w formie dobrych praktyk, określonych wyznawanymi przez rodziców rozległymi rozumnymi doktrynami (Rawls), które powinny zostać uogólnione i wyrównane na poziomie szkoły w formie odpowiednich treści nauczanej wiedzy. Jeśli uwzględnimy teraz rozważania Bourdieu, to może się okazać, iż uzyskany konsens polityczny, wynikający $z$ uznania wartości idei sprawiedliwości i stanowiący podstawę dobrze urządzonego społeczeństwa, jest jedną $z$ form kulturowej dominacji.

To drugie wskazane przeze mnie zagrożenie $\mathrm{w}$ pewien sposób może niwelować analizowane przez Bourdieu różnice związane $z$ dostępem do kapitału kulturowego. Przy czym może chodzić o niwelowanie w sensie dosłownym, to znaczy zrównanie przez obniżenie ogólnego poziomu kultury, w tym także kultury politycznej. Do czasów rewolucji internetowej obszarem, w którym mogły się manifestować postawy i uczucia obywateli, czyli ich kultura polityczna, pozostawała sfera publiczna, zakreślona granicami państwa narodowego i forma jego ustroju. I właśnie w tym obszarze dochodziło, paradoksalnie przez konflikt, do uzgodnienia kultur, w tym także kultur politycznych. Jak zauważyli Almond i Verba:

Konflikty zwiazane $z$ kulturami politycznymi mają wiele wspólnego $z$ konfliktami kulturowymi w ogóle, a procesy prowadzące do przyswojenia sobie kultury politycznej (acculturative processes) staja się bardziej zrozumiałe, kiedy rozpatrujemy je $z$ punktu widzenia charakterystycznych dla ogólnych przemian kulturowych zjawisk oporu, tendencji przenikania i wchłaniania jednych przez drugie ${ }^{26}$.

${ }^{26}$ Por. G.A. Almond, S. Verba: The Civic Culture, s. 13. 
Zmieniała się podstawa techniczna sfery publicznej, techniczne nośniki komunikacji: druk nadał jej formę „galaktyki Gutenberga”, rozwój radia i telewizji wytworzył „galaktykę Marconiego”27. Te zmiany nie miały jednak zasadniczego wpływu na pełnione przez nią funkcje, w tym wspomnianą wyżej funkcję uzgadniania kul$\operatorname{tur}^{28}$. Dokonujaca się obecnie rewolucja technologiczna, przybierajacca formę przełomu informatycznego, w sposób wyraźny zmienia nie tylko kształt samej sfery publicznej, ale również sposób, w jaki w niej uczestniczymy. Proces ten można opisać jako przejście od społeczności („republiki”) ludzi czytających, jaką była od oświecenia sfera publiczna do społeczności wirtualnej (Facebook). W sposób oczywisty transformacja taka wspomaga procesy związane $z$ globalizacja, a nawet uznać można, iż sama te procesy inicjuje. Za jej sprawa dokonują się bowiem zmiany, które zarówno maja wpływ na sposób, w jaki rozumiemy dzisiaj samych siebie, określamy naszą tożsamość, jak i oddziałują na sposób poznawania i rozumienia otaczającego nas świata. Wśród mających taki skutek konsekwencji rewolucji informatycznej wymienia się m.in: zageszczenie relacji czasowych i przestrzennych; powstanie jednego globalnego czasu (epoka live, online); rozwinięcie telenadzoru, który według niektórych filozofów stanowi zapowiedź globalitaryzmu, a także traktowanie informacji jako trzeciego wymiaru materii wraz $z$ masa i energią. Wytworzyła się także nowa forma kultury, czyli cyberkultura ${ }^{29}$.

\footnotetext{
${ }^{27}$ Tego rodzaju metaforę, czyli pojęcie „galaktyki Gutenberga”, wprowadził Marshall McLuhan w badaniach nad wpływem środków przekazu na kulturę i tożsamość człowieka. To nowe, technologicznie uwarunkowane środowisko człowieka przyrównał do kosmicznych galaktyk stanowiących związany grawitacyjnie układ gwiazd, pyłu i gazu międzygwiazdowego oraz niewidocznej ciemnej materii. Por. M. McLuhan: Wybór tekstów, przekład E. Różalska, J.M. Stokłosa, Zysk, Poznań 2001.

${ }^{28}$ Por.: J. Habermas: Strukturalne przeobrażenia sfery publicznej, przekład M. Łukasiewicz, W. Lipnik, Państwowe Wydawnictwo Naukowe, Warszawa 2008, s. 330-331.

${ }^{29}$ Do cyberkultury zalicza się różne fenomeny związane $z$ Internetem oraz nowymi formami sieciowej komunikacji, takie jak np.: sieciowe społeczności, wieloosobowe gry sieciowe, kwestie tożsamości sieciowej, socjologia i etnografia wykorzystania poczty elektronicznej, użycie telefonów komórkowych w różnych społecznościach; kwestie gender i etniczności w Internecie.
} 
Wśród filozofów zajmujących się tą nową cyfrową rzeczywistością przeważa dość pesymistyczny pogląd zwiąany z jej wpływem na sferę publiczną. Zwraca się uwage na specyfike relacji, jakie ukształtowały się w Sieci. Ponieważ każdy użytkownik Internetu jest przede wszystkim nadawca, zauważają oni, iż zanika debata publiczna jako podstawowa forma istnienia sfery publicznej. Zglobalizowana sfera publiczna, wbrew nadziejom wielu liberalnych filozofów polityki, nie prowadzi do wzbogacenia takiej debaty dzięki różnorodności opinii czy wielokulturowości, a wręcz przeciwnie: coraz więcej zjawisk dowodzi, iż dokonuje się w jej obszarze kulturowa homogenizacja, szczególnie w obszarze zbiorowych wyobrażeń (upadek lokalnych symboli) w coraz większym stopniu kolonizowanych przez kulturę masowa. Towarzyszy temu nasilajacy się konsumpcjonizm (Habermas) oraz, jak twierdzi Paul Virilo, urynkowienie spojrzenia (percepcji). Ponieważ konsumpcjonizm jest efektem oddziaływania na ludzkie potrzeby i pożądania, zaczynają one dominować w owym zmiksowanym obszarze publicznym, co sprawia, że nabiera on charakteru nieracjonalnego, gdyż przeważaja $\mathrm{w}$ nim emocje. W związku $z$ tym grozi nam, według niego, niebezpieczeństwo podobne do zatrucia naturalnego środowiska, które może wynikać $z$ postępującej digitalizacji wszelkich informacji (wzrokowych, słuchowych, dotykowych i węchowych), co prowadzi do zaniku bezpośredniej percepcji. Dokonuje się skażenie podstawowych kategorii dotyczacych poznania, w tym przede wszystkim kategorii reprezentacji, czyli przedstawienia. Zdaniem Virilio, reprezentacja w warunkach cyberprzestrzeni zmienia się $\mathrm{w}$ prezentację. Ta nowa przestrzeń publiczna jest zdominowana przez nadawcę i służy, jak chce Virilio, zaznaczaniu i pielęgnowaniu własnej odmienności. W coraz większym stopniu traci charakter sfery publicznej i zostaje zdominowana przez subiektywna prywatność. Kiedy jednak dochodzi do upublicznienia intymności, to zostaje podważona tradycyjnie rozumiana granica między tym, co publiczne, a tym, co prywatne oraz zwiazane $z$ nia normy i obyczaje. Ponieważ nasze zmysłowe doświadczenie stanowiło 
o możliwości orientacji w przestrzeni, przede wszystkim możliwości określenia tego, co bliskie i współmierne oraz tego, co dalekie i niewspółmierne, zaczynamy mieć problemy $z$ określeniem właściwego dystansu ${ }^{30}$. A przecież wyrobienie sobie opinii na dany temat, nabycie określonych przekonań politycznych, bez czego trudno mówić o kulturze politycznej, wymaga zrozumienia własnej sytuacji, co jest możliwe jedynie dzięki nabraniu wspomnianego dystansu. To właśnie dystans i jego kształtowanie stanowił konstytutywny element dawnej formy sfery publicznej, stanowiąc warunek postawy krytycznej. Badajac, $z$ punktu widzenia fenomenologa, ten związek między sfera publiczna a wyrobieniem sobie własnego zdania na temat wspólnego świata, Klaus Held stwierdził: „Bycie widzianym i słyszanym przez innych czerpie swe znaczenie $z$ faktu, że każdy widzi i słyszy z innego miejsca"31. Taka odmienność perspektyw według niego konstytuuje wręcz sferę publiczną i decyduje o otwartości świata politycznego, która jest możliwa, jak twierdzi dalej Held: „[...] dzięki wielości mniemań licznych obywateli, która uwarunkowana jest przez światowo odrębne punkty wyjścia ich sądów ${ }^{32 "}$. Oznacza to, iż sfera publiczna $z$ istoty ma charakter pluralistyczny, a próby ujmowania jej w kategoriach jedności $z$ punktu widzenia czy to prawdy absolutnej, nauki (episteme), czy to subiektywności niszcza jej swoistośćc ${ }^{33}$. Nowa, warunkowana przez cyberkulturę sfera publiczna, w której każdy może wygłaszać swój własny prywatny monolog, nie troszczac się o zdanie innych jej uczestników i nie obawiając się sankcji, z jakimi dotychczas spotykały się wypowiedzi brutalne, źle sformułowane czy po prostu głupie, coraz bardziej traci charakter obszaru wspólnego, przestaje być publiczna. Wydaje mi się jednak, iż to nie uprywatnienie opinii stanowi największe dzisiaj niebezpieczeństwo dla istnienia sfery

\footnotetext{
${ }^{30}$ Por. P. Virilio: Bomba informacyjna, przekład S. Królak, Wydawnictwo Sic!, Warszawa 2006. ${ }^{31}$ Por. K. Held: Fenomenologia świata politycznego, przekład A. Gniazdowski, Wydawnictwo Instytutu Filozofii i Socjologii PAN, Warszawa 2003, s. 34 i nn. W tym względzie podejmuje Held polemikę z ujęciem sfery publicznej przez Jürgena Habermasa i Karla-Otto Apla.

32 Ibidem, s. 35.

${ }^{33}$ Por.: T. Buksiński: Publiczne sfery i religie, Wydawnictwo Naukowe Instytutu Filozofii Uniwersytetu Adama Mickiewicza w Poznaniu, Poznań 2011, s. 32-33.
} 
publicznej. Raczej tym, co może doprowadzić do jej unicestwienia, jest właśnie jej umasowienie. Podobnie jak Held, a wcześniej José Ortega y Gasset, uważam, że społeczeństwo masowe niszczy zarówno dziedzinę publiczna, jak i prywatna, pozbawiając ludzi nie tylko ich własnego miejsca na świecie, ale i prywatnego domu. Za sprawa umasowienia dokonuje się bowiem deprywacja prywatności, czego efektem staje się jej deprawacja. Prywatność może istnieć i stanowić obszar realizowania wartości tylko wtedy, kiedy jest obszarem wyróżnionym i zindywidualizowanym $\mathrm{w}$ stosunku do wspólnego świata.

Pojawia się zatem pytanie, w jaki sposób w warunkach tej nowej, zdeformowanej przez „subiektywna prywatność” i zapośredniczonej przez lawinowy postęp nowych środków komunikacji powinna funkcjonować kultura polityczna. Podjęte przez znawców kultury politycznej badania empiryczne pokazały, w jak dużym stopniu jest ona uzależniona od ogólnej kultury, rozumianej nie tyle jako działalność twórcza i jej wytwory, ile w znaczeniu zestawu norm i wartości regulujacych relacje społeczne. W takim ujęciu kulturę polityczna należy traktować jako już istniejące, zastane zjawisko; wprawdzie dynamiczne, ale dające się przekazywać przede wszystkim w toku procesu kształcenia nowego pokolenia: jest przekazywana i nabywana jako tradycja, i to nie tylko w sensie Rawlsowskich rozległych rozumnych doktryn. Jeśli wychowanie $\mathrm{w}$ rodzinie $\mathrm{z}$ konieczności stanowi podstawę całego procesu wychowania, oznacza to również, iż przygotowuje dziecko do dalszej edukacji, kształcąc w nim kompetencje usprawniajace przyswajanie wiedzy i pozwalające ja mądrze wykorzystywać. Dotyczy to również wiedzy i umiejętności związanych z kultura polityczna, do której nawiązywać powinno wychowanie w rodzinie. I może się to dokonywać jedynie dzięki oddziaływaniu innych ludzi, wzorów osobowych (wychowawców), a nie za sprawą symulacji idealnej formy społeczeństwa, jak chciałby tego Rawls.

Powiazanie procesu obywatelskiej edukacji $z$ oddziaływaniem systemu politycznego, jeśli nawet byłby on zbudowany w odwołaniu 
do idei dobrze urzadzonego, sprawiedliwego społeczeństwa, i tak wymaga najpierw pojawienia się ludzi, którzy tworza takie społeczeństwo, czyli sami nie przeszli tego rodzaju edukacji. Dlatego warto, jak sądzę, podejmując wysiłek nauczania kultury politycznej, którego nie wolno nam zaniechać, pamiętać o wskazaniach Kanta, według którego wychowanie powinno przede wszystkim uczyć myślenia, to znaczy należy doprowadzić dziecko do uznawania zasad, $z$ których działania dopiero wynikaja, a nie narzucać mu gotowych form owego działania. 